\title{
STUDY REGARDING THE CORRELATION BETWEEN THE ACADEMIC AND PROFESSIONAL ENVIRONMENT FROM THE PERSPECTIVE OF FUTURE GRADUATES. MANAGERIAL ACCOUNTING CASE
}

\author{
Gabriela Lidia Tănase ${ }^{1}$ \\ Aurelia Ştefănescu ${ }^{2}$
}

\begin{abstract}
In a turbulent economic environment, characterized by a downward trend of financial resources and jobs offer, professional environment requirements are increasing, and thus, the academic environment's role is becoming major. These were the coordinates that have directed our empirical research on analyzing the perspective of future graduates regarding the correlation between the academic and professional environment in the field of managerial accounting. The research approach considers on one hand, a synthesis of ideas published on this subject in the literature. This is complemented by an empirical study based on a questionnaire to which we have received responses from future graduates of the academic environment in the accounting field. The study results showed that all respondents believe that accounting education is correlated with the professional environment, the academic environment offering them the necessary training in managerial accounting for a successful integration into the professional environment. The majority of respondents also believes that for the integration in the professional environment, future graduates must hold simultaneously theoretical and practical knowledge, but also organizational skills. The results reveals that, by their relevance, the factors that motivate future graduates to prepare in managerial accounting are: the interest to acquire knowledge, labor market integration, discipline content, professor's teaching methods, the promotion of the exam. Also, all respondents would accept to participate in volunteer programs organized by the professional environment in order to gain experience in managerial accounting. Regarding the adaptation of the managerial accounting approach in the academic environment, most respondents support a moderate adjustment by implementing internship and volunteering programs.
\end{abstract}

Keywords: academic environment, professional environment, managerial accounting, future graduates

JEL Codes: M41, I25

\section{Introduction}

The premise of this study was the existence of an interdependent relationship between the economic, professional and academic environment. Taking into consideration the dynamic economic environment, accounting becomes a challenging field both for the academic and for the professional environments. In this context, our research is two-dimensional: the first dimension of the research considers the conceptual assertions regarding the interrelation between the professional and academic environments in terms of accounting, and the second dimension, investigates the future graduates opinion regarding the correlation of the management accounting knowledge gained in the academic

\footnotetext{
${ }^{1}$ The Bucharest University of Economic Studies, Romania, e-mail: gabrielatanase26@yahoo.com

2 The Bucharest University of Economic Studies, Romania, e-mail: stefanescu.aura@gmail.com
} 
environment with the expectations of the professional environment. We believe that such an approach will contribute to the increase of the academic environment role and will develop the cooperation between the academic and professional environment in order to integrate successfully future graduates in the professional environment.

\section{Conceptual assertions concerning the correlation of the academic and professional environment- accounting perspective}

The changes that occurred in the business environment, such as the increase of the environment volatility and of the competition in the field of activity, like the development of communication and technology information, or business globalization and the increased importance given to the knowledge capital, as well as the changes occurred in stakeholders expectations, led to the appearance of changes in accounting practice (Howieson, 2003), and have also generated changes in activity management and in the managerial accounting practices. From this perspective, research that highlights the limits of budgets recorded an upward trend, although budgets are recognized as managerial accounting tools useful in operational planning, resource allocation, objectives communication, activity coordination and delegation, subordinates motivation and empowerment, activities control, performance evaluation and rewards calculation (King et al., 2010; Huang and Chen, 2009; Hansen and Van der Stede, 2004; Joshi et al., 2003; Reid, 2002). Budgets are often seen as outdated in a dynamic business environment, characterized by a fierce competition, as it limits the development and the adaptability of the entity to the environment, promotes an unproductive behavior, and because they are not connected with the strategy and structure of the entity, they are not oriented towards customer and quality and they are not dynamic or updated (Bourmistrov and Kaarbøe, 2013; Libby and Lindsay, 2010; Nelly et al., 2003; Ahmad et al., 2003; Bunce et al., 1995). Therefore, the economic entities may operate changes in managerial accounting practices. For example, some entities have given up budgets, while others continue to use budgets in their current form or in an improved form.

In this context, the expectations of the professional environment for future employees change, influencing the abilities they are required to have. International studies attribute employees the role of 'knowledge' workers, including among the knowledge and skills they must possess to meet the demands of the professional environment: strategic skills, measuring and reporting abilities, management skills, knowledge of cost and evaluation, management, business and tax law knowledge, information technology skills, analysis and innovative problem solving abilities, communication and risk analysis skills, etc. (see Howieson, 2003; Lin, 2008). Therefore, multidisciplinary and managerial skills become fundamental to any graduate aspiring to become an employee of any economic entity.

Okofo et al. (2011) discuss the academic environment by taking into consideration the importance it has on the professional environment. The authors consider that the academic environment is one of the factors that influences accounting and reporting practices of Ghana economic entities, because a high level of education leads to a better understanding and use of accounting standards.

Helden et al. (2010) argues for the collaboration of the academic environment with the professional one, because both contribute to the improvement of knowledge in accounting. From the perspective of the public sector managerial accounting, the authors mention three actors that contribute to the creation of knowledge: consultants, researchers and consultants-researchers. Consultants provide knowledge that is based on problems encountered in the professional environment and is intended for practice. They have limited access to academic research, mainly due to the pressure felt at the work place. As for researchers, although they understand the importance of the professional environment, they encounter problems in reconciling it with the research, mainly due to the pressure to publish in international journals and due to their limited contact with consultants. Consultants-researchers remove 
the communication barrier between consultants and researchers, since they use research to reflect the theoretical aspects of the work environment.

In another vision, Kutuluk et al. (2012) discuss the importance of the feedback coming from professional accountants for the academic environment and the need for a better collaboration between accountants and the academic field. The authors provide as an argument the results concerning the opinion and expectations of Antalya Certified Public Accountants on universities accounting education, which have shown that students do not have, at graduation, sufficient knowledge of accounting and that courses are not consistent with the needs of economic entities. That is why, the new knowledge that graduates should possess, must generate changes in the academic environment, resulting in the development and adoption of analytical and interdisciplinary courses and teaching methods able to respond to the changes that will occur in the competence of future professional accountants (Howieson, 2003).

Instead, Boyce (2004) mentions that although the academic environment focuses on preparing students for the professional environment and on its requirements for training future employees, the academic environment's role should not be limited merely to accounting practice skills development.

The approach presented at a conceptual level, highlights that the changes in the professional environment requirements should be reflected in the academic environment, which has a major role: to develop the professional judgment and to prepare and form the required skills of future graduates for a successful integration in the labor market. Also, the academic environment has the mission to continuously adapt to the dynamics of the professional environment, to develop innovative methods and techniques to provide future graduates the newest knowledge aligned with the practice in the field of study. Therefore, the correlation between the academic and the professional environments will contribute to the improvement of knowledge in the accounting field by developing the concept of research for practice.

\section{Study regarding the correlation of the academic environment with the professional field in the vision of future graduates. Managerial accounting case \\ 2.1 Research objectives and methodology}

Our research aims to investigate the opinion of future graduates on the relationship between the knowledge gained through the managerial accounting discipline over the years of study and the professional environment requirements. To this end, we used as a scientific research methodology, the quantitative research, developing a questionnaire which includes 15 questions. The first twelve questions refer to the future graduates' opinion concerning the professional environment requirements, the ability of the academic environment to offer them the necessary training for labor market integration, the opportunity to improve their knowledge provided by the academic environment and related alternatives. The last three questions include general identification coordinates for respondents as their home city, age and sex. The study population includes third year students from the Faculty of Accounting and Management Information Systems from the Bucharest University of Economic Studies. The selected sample is considered to be representative. During the period February-March 2014 we distributed 140 questionnaires in a physical form to future graduates. We gathered 111 questionnaires, from which 104 were valid. In terms of general coordinates of the respondents, $40.38 \%$ are from Bucharest and 59.62\% from another town. The majority of respondents $(87.50 \%)$ were female and the average age of the respondents was 21.49 years old. 


\subsection{Results of the study}

Regarding the opinion of future graduates on the expectations of the professional environment from graduates who want to work in managerial accounting, the responses revealed the following: $56.73 \%$ of respondents consider that in order to be validated by the professional environment, future graduate should possess a mix of knowledge, namely theoretical, practical and organizational skills; $35.58 \%$ of respondents believe that the working environment expects graduates to possess practical knowledge; $8.65 \%$ consider important for integration into practice theoretical knowledge and only $1.92 \%$ of respondents consider that the professional environment is relying on the organizational skills of the potential employee (Figure 1).

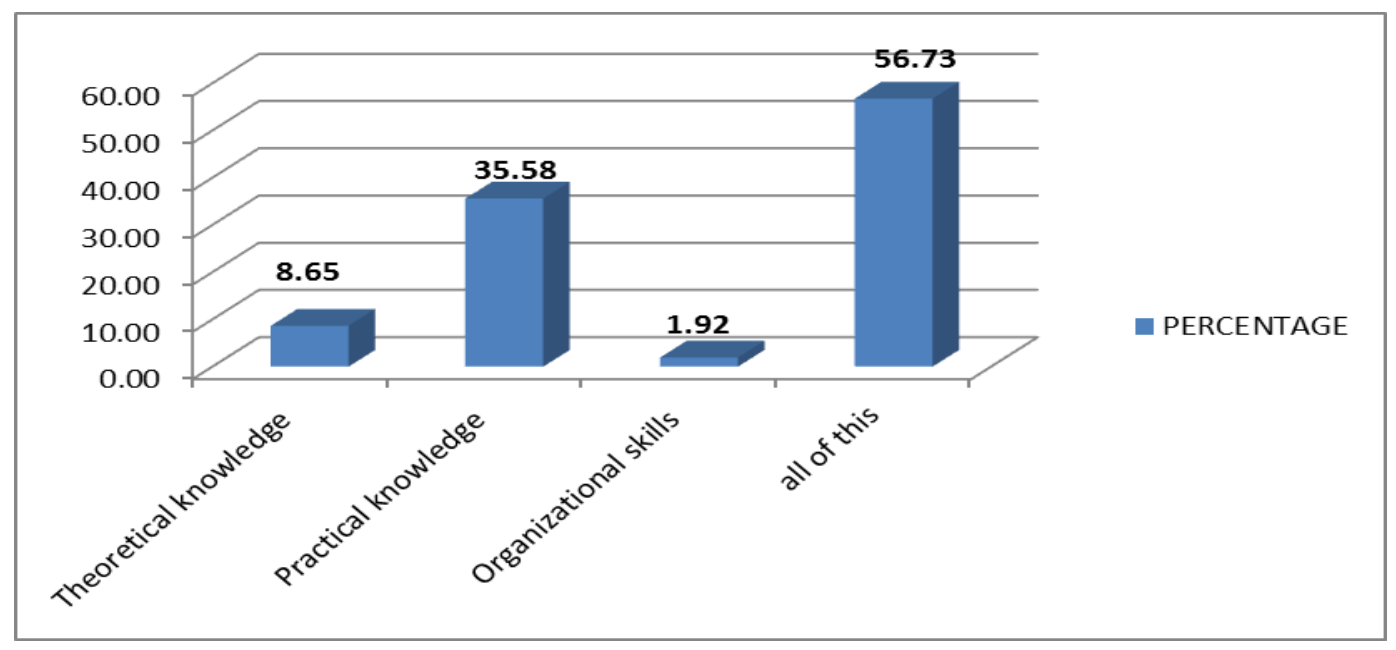

Figure no. 1 - Expectations of the professional environment from graduates seeking to work in managerial accounting

Concerning the degree of correlation between managerial accounting knowledge gained from the academic environment and the requirements of the professional environment, $84.62 \%$ of future graduates believe that managerial accounting education is correlated with the professional environment and only $15.38 \%$ believe that professional environmental requirements are reflected in a small degree in the academic education (Figure 2).

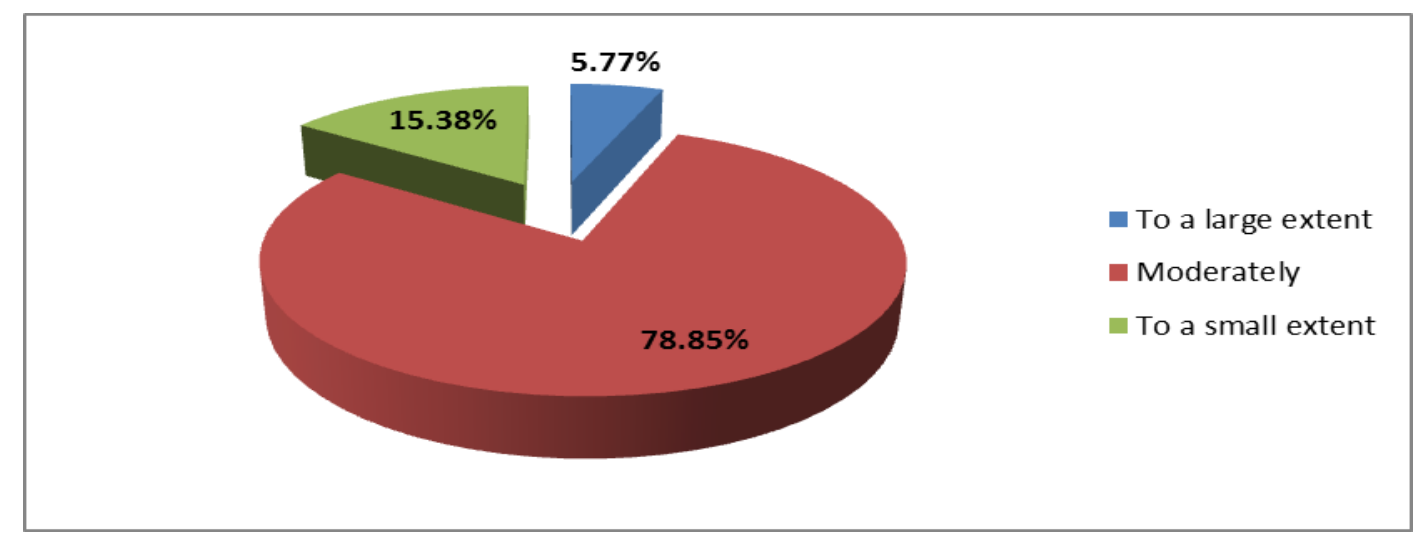

Figure no. 2 - The correlation of the professional environmental requirements with the education received in the academic environment in the field of managerial accounting 
Also, a significant percentage $(72.11 \%)$ of respondents believes that the academic environment provides them with the necessary training in managerial accounting for a successful integration into the labor market. The remaining respondents consider that they are prepared to a small extent to integrate in a professional environment (Figure 3). Respondents' low option for a large correlation of the professional environmental requirements with the education received academically, as well as for the ability of the academic field to provide the necessary training for a successful professional integration, can be explained by the fact that economic entities carry out, before the selection of future employees or at the beginning of the employment period, professional training courses.

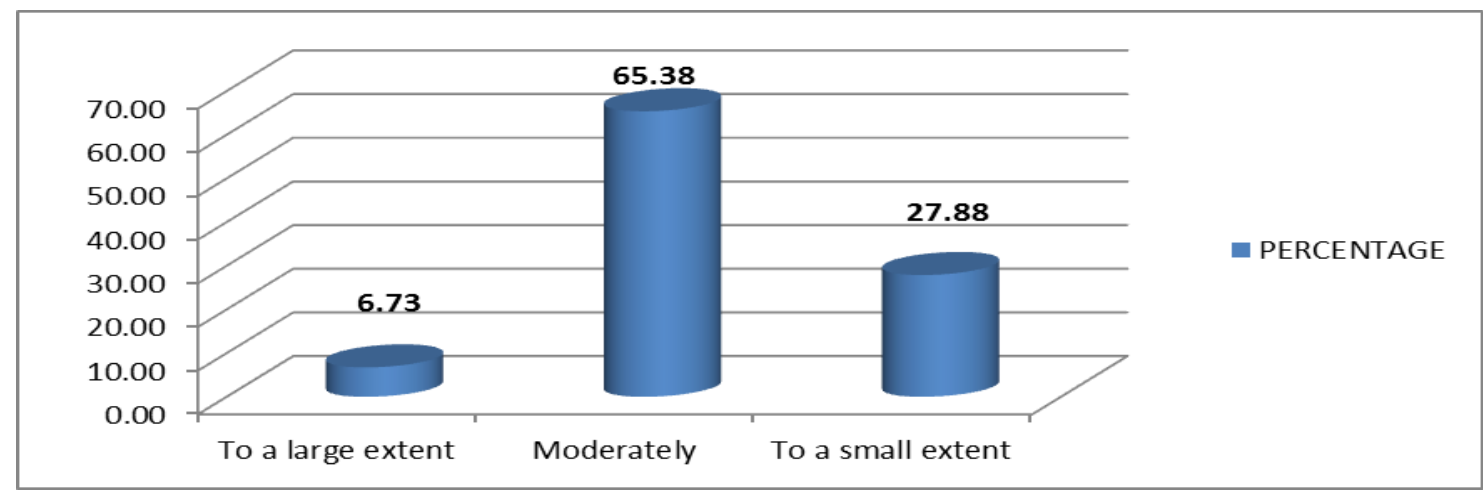

Figure no. 3 - Academic environment's ability to provide the necessary training for a successful integration in professional environment of managerial accounting

Analyzing the applicability in the professional environment of the knowledge acquired at managerial accounting during university studies, $71.15 \%$ of respondents selected the moderate or high option of the question. The limited applicability of theoretical knowledge in practice, attributed by respondents, may be due to the fact that the way of organizing the management accounting represents the option of economic entities, and their number may be limited (Figure 4). Also, the activity of the entities, their size, the performance objectives and additional costs (software and staff) are factors that influence the way of organizing the managerial accounting and by default the number of professionals applying managerial accounting. However, overall, most respondents believe that managerial accounting knowledge gained in the academic environment gives them more chances of integration into the labor market (Figure 5).

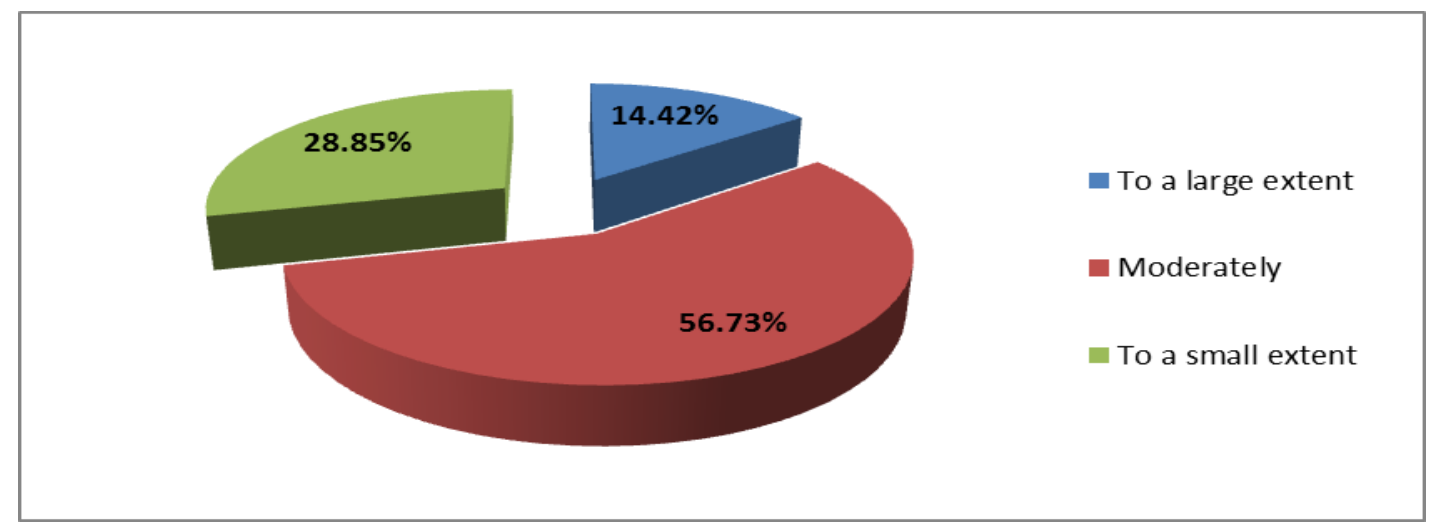

Figure no. 4 - The applicability in practice of managerial accounting knowledge gained during the academic studies 


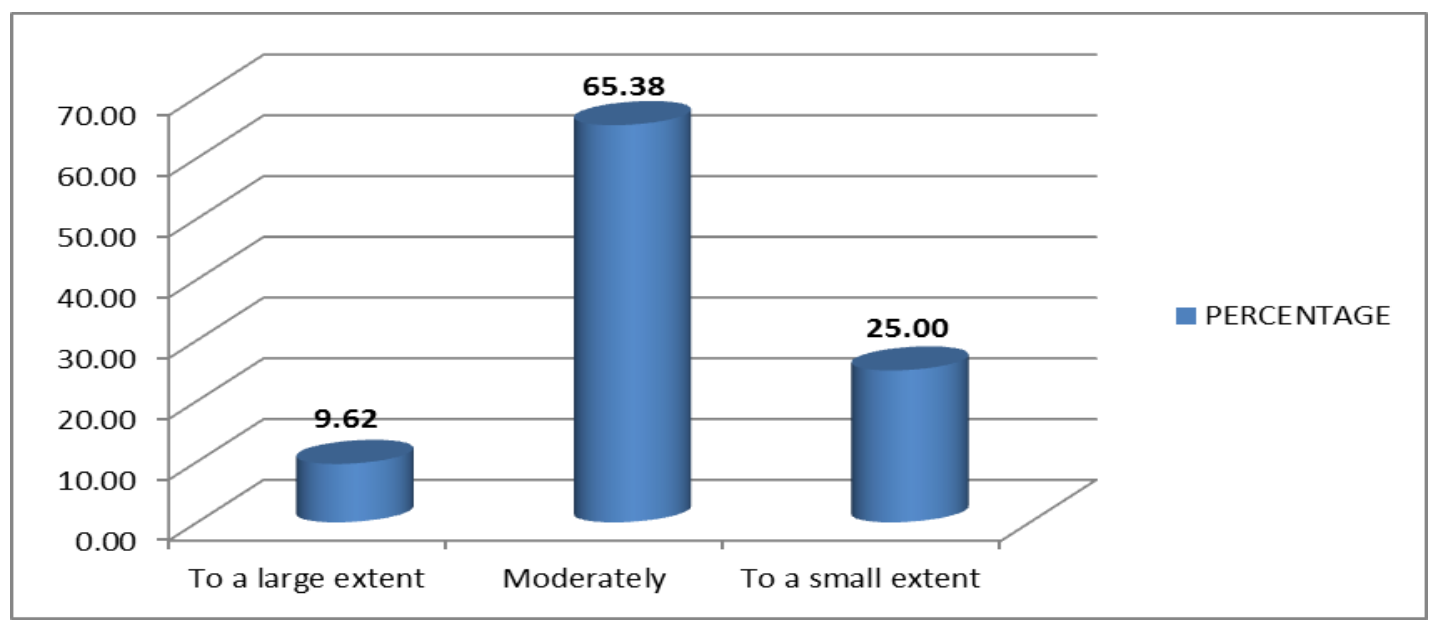

Figure no. 5 - The degree to which the knowledge gained in the academic environment facilitates the access to the professional environment

Regarding the impact of the managerial accounting knowledge gained during university studies on employers' decision, $22.12 \%$ of respondents believe that it records a high level and $59.62 \%$ consider it to be moderate. $18.27 \%$ of respondents believe that the employers' decision is influenced to a small extent of the managerial accounting knowledge held by a potential employee (Figure 6), opinion which can be explained by the possible limited number of economic entities in which management accounting operates.

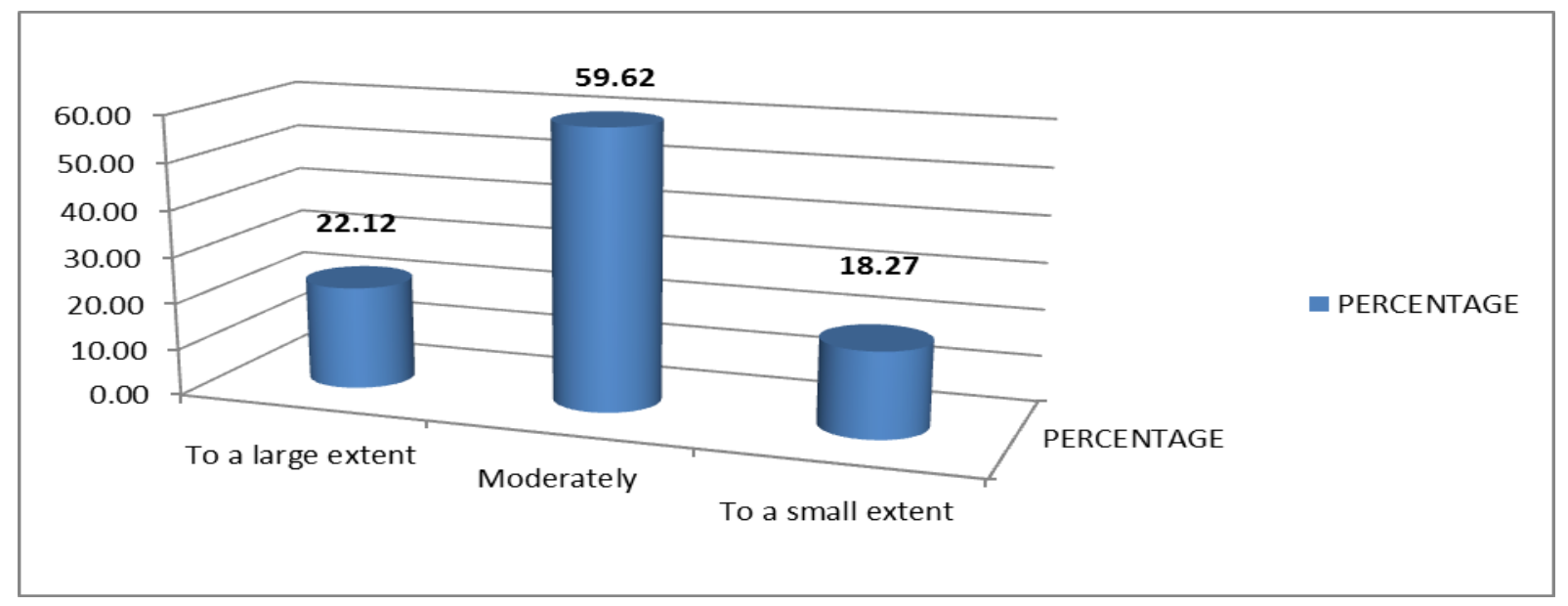

Figure no. 6 - The impact of managerial accounting knowledge gained in the academic environment on employers' decision

The correlation between managerial accounting knowledge gained by future graduates in the academic environment and employers' decision stimulates accounting education. The analysis of Chart 7 shows that future graduates are motivated primarily by the interest to acquire as much knowledge as they can (3.49 points), followed by the desire to integrate into the labor market (3.40 points). The discipline contents (3.36 points), the professor's way of teaching (3.31 points) and the promotion of the exam (3.01 points) also motivates future graduates to acquire knowledge in managerial accounting. 


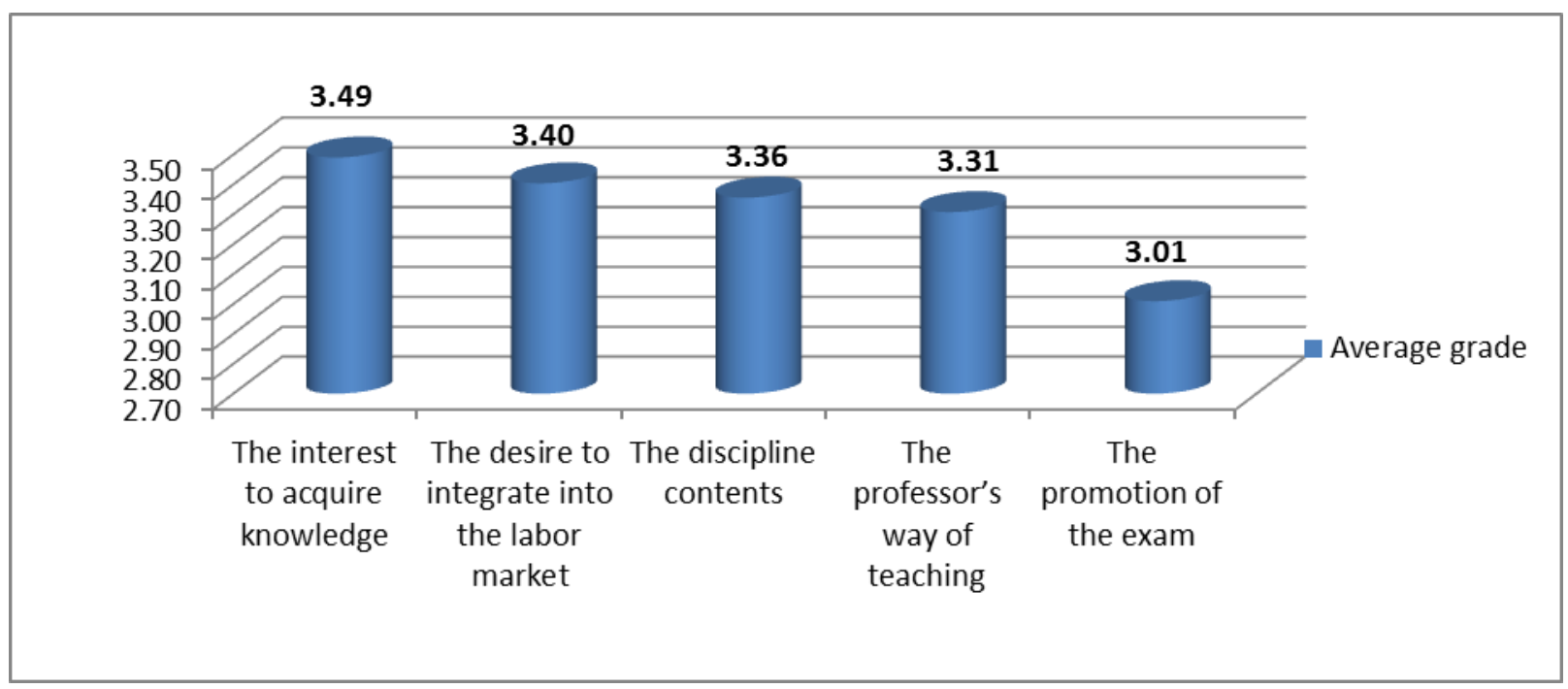

Figure no. 7 - Motives for acquiring knowledge in managerial accounting

Regarding the professional experience gained in managerial accounting, most respondents stated that they have not accumulated experience in this field through jobs, internships, participation in internships, or by any other means. Thus, only 37 of the 104 respondents stated that they have practical experience in managerial accounting. Of the 37 initiated accounting professionals, $75.68 \%$ have applied in practice, to a large or moderate extent, the managerial accounting knowledge gained academically. The value of the professional experience is mainly recognized by future graduates, 91.35 $\%$ of them being willing to participate in voluntary programs conducted within entities to acquire experience in managerial accounting (Figure 8). The respondents' opinion can be justified by the fact that one of the criteria for recruitment of future employees by economic entities is previous work experience.

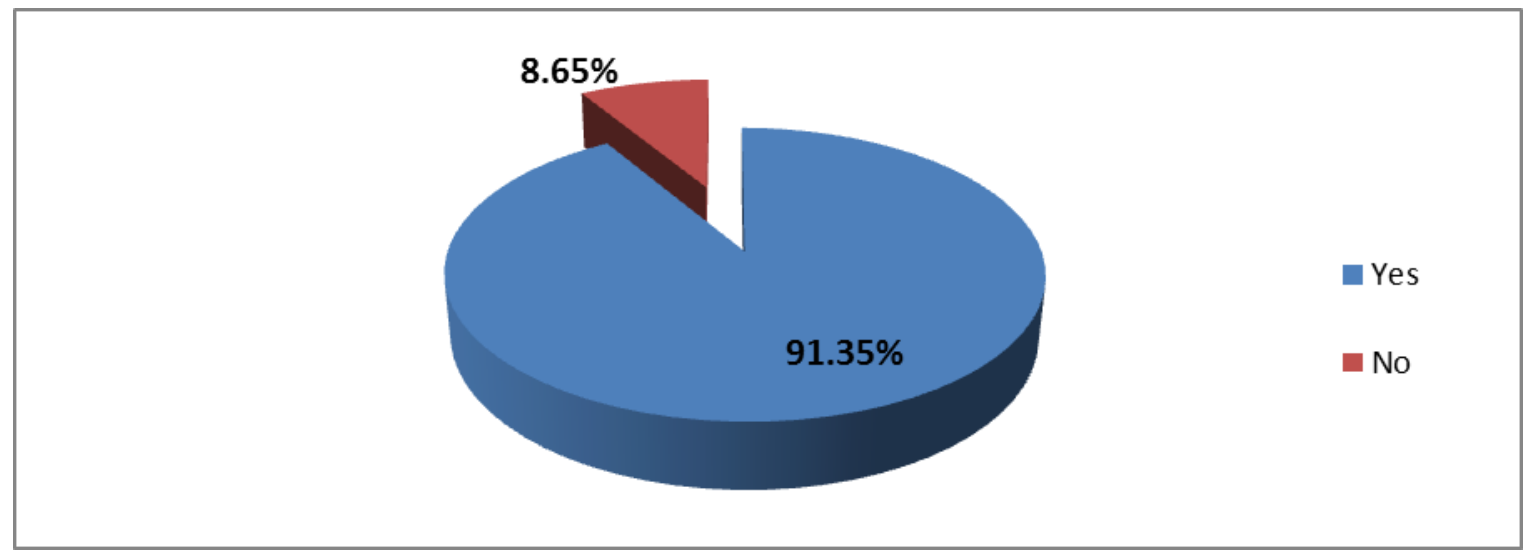

Figure no. 8 - Students' availability to participate in voluntary programs to gain professional experience in managerial accounting

The objective of future graduates of a more professional integration of managerial accounting even as early as their university studies is reflected in the respondents' opinion regarding the adjustment of the approach of the managerial accounting discipline. From this point of view, $35.08 \%$ of respondents believe that it should be adapted to a large extent, $48.08 \%$ of respondents chose the 
moderate version, $15.38 \%$ believe that it should be adapted to a small extent, and $0.96 \%$ do not consider necessary to adapt the current approach of the discipline (Figure 9).

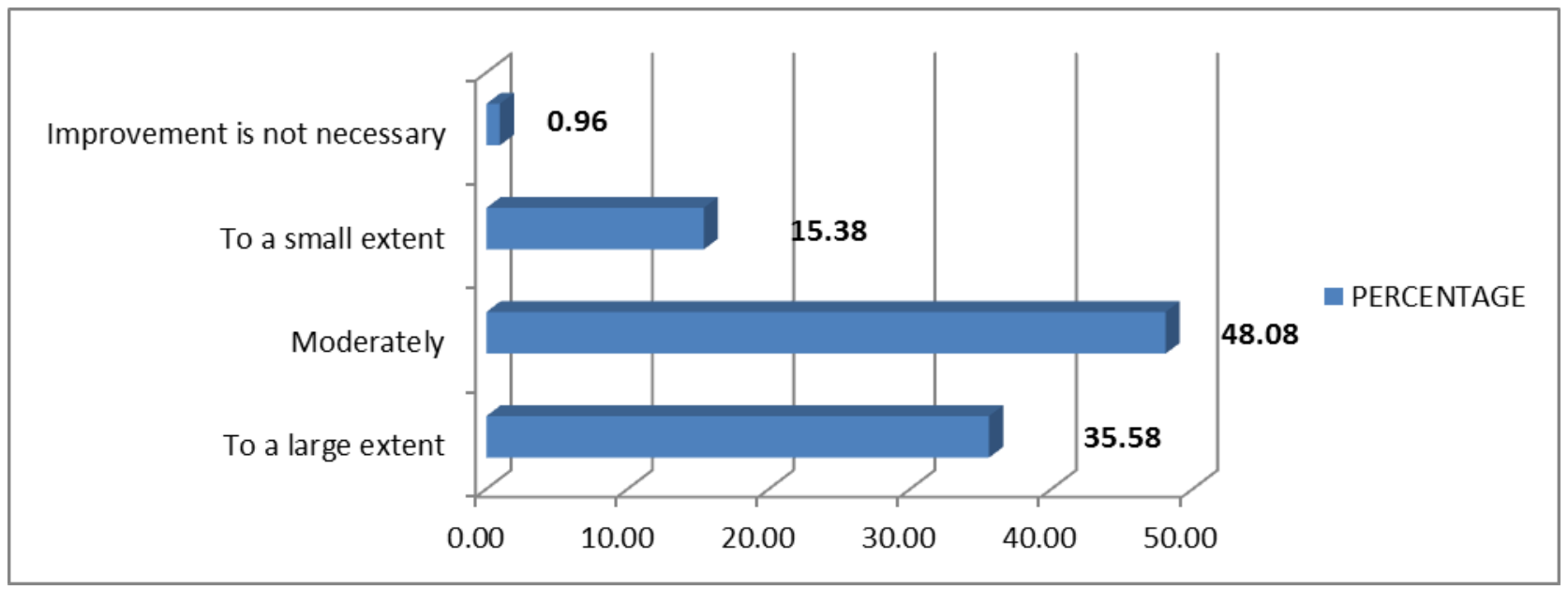

Figure no. 9 - The need to adapt the approach of managerial accounting discipline

Looking at ways considered appropriate by the respondents to adapt the approach of the discipline, we found that $39.42 \%$ of them propose the implementation of internship or volunteering programs, etc. in managerial accounting, 25.96\% support the prevalence of practice in management accounting and a negligible proportion of respondents $(2.88 \%)$ propose the changing of the teaching system. $46.15 \%$ of the total number of respondents believe that changes should be done in an integrated manner, incorporating all of the above suggestions (Figure 10). The respondents' options could be explained by the fact that internship programs offered by economic entities, practice stages and other programs used to integrate future graduates in the professional environment, although many and varied, are limited in terms of managerial accounting.

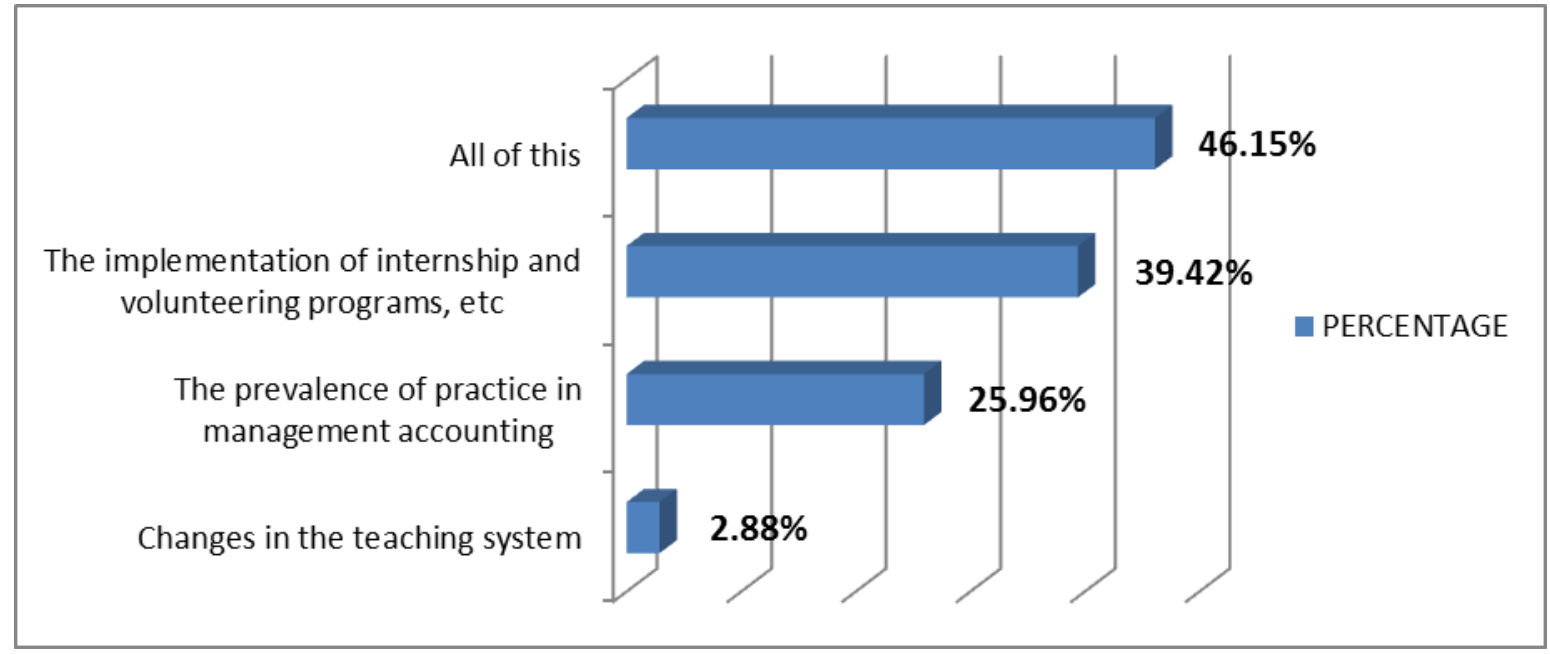

Figure no. 10 - Main ways of adapting managerial accounting discipline 


\section{Conclusions}

The research made at a conceptual level, highlights the importance of the academic environment for the professional one, as well as the need of correlations between the academic and professional environments, for training, cognitive growth and professional judgment development of future graduates in line with the professional trends.

From the perspective of the empirical research regarding the opinion of future graduates on the correlation between the academic and professional environments in the field of managerial accounting, the results showed the following:

- $56.73 \%$ of the respondents believe that for a professional integration, future graduates must have a mix of knowledge, namely theoretical, practical and organizational skills; $35.58 \%$ of them believe that for the professional environment practical knowledge prevails; a small proportion of respondents consider important to integrate in practice only the theoretical knowledge or only the organizational skills of the potential employee;

- $84.62 \%$ of future graduates believe that accounting education is correlated with the professional environment;

- $72.11 \%$ of respondents believe that the academic environment provides them with the necessary training in managerial accounting for a successful professional integration;

- $71.15 \%$ of respondents felt that the knowledge gained in the academic environment has applicability in practice;

- The majority of respondents believes that the accounting education of the academic environment provides them with greater chances of professional integration;

- Most respondents have not acquired professional experience in managerial accounting through jobs, internships, or other means. Of the ones already initiated in the accounting profession, 75.68\% applied in practice, to a large or moderate extent, the managerial accounting knowledge gained in the academic environment;

- $22.12 \%$ of the respondents believe that employers' decision is significantly influenced by the managerial accounting knowledge gained in the academic environment; $59.62 \%$ believe that employers' decision is influenced in a moderate extent and $18.27 \%$ think that employers' decision is influenced to a small extent by the managerial accounting knowledge held by a graduate;

- The factors which motivate future graduates to prepare themselves in managerial accounting were prioritized as follows: interest to acquire knowledge; labor market integration; discipline content; professor's teaching methods; the promotion of the exam;

- The majority of respondents $(91.35 \%)$ would agree to participate in voluntary programs conducted within economic entities in order to acquire experience in managerial accounting;

- $48.08 \%$ of respondents support the moderate adaptation of the management accounting approach in the academic environment; $35.08 \%$ of respondents believe that it should be adapted to a large extent, $15.38 \%$ opted for a small adjustment and $0.96 \%$ were satisfied with the current approach.

- The ways considered appropriate by the respondents to adapt the approach of the discipline are: implementation of internship or volunteering programs $(39.42 \%)$; prevalence of practice in management accounting (25.96\%); changes to the teaching system $(2.88 \%)$; and an integrated adaptation, incorporating all of the above suggestions.

Based on the results of our research we conclude that although the academic environment provides future graduates with the adequate accounting education for a successful integration in the professional environment, students being motivated to learn managerial accounting, in particular to gain knowledge and to be professionally integrated, they consider necessary to adapt the management accounting approach to the perspective of professional environment. 
In regards to our research limitations, we believe that one of the major restrictions affecting the comparability in the academic environment is that fact that we analyzed only the information provided by future graduates of one faculty of a single academic center. However, it is known that in the academic environment the principle of university autonomy is applied, therefore, the approach of the managerial accounting discipline is heterogeneous.

\section{Acknowledgment}

This work was supported from the European Social Fund through Sectorial Operational Program Human Resources Development 2007 - 2013, project number SOPHRD/156/1.2/S/133202, project title "Harmonization through innovation in the knowledge assessment in the Accounting domain"

\section{References}

1. Ahmad N. N. N., Sulaiman M., Alwi N. M., 2003. Are budgets useful? A survey of Malaysian companies, Managerial Auditing Journal, Vol. 18, No. 9, pp. 717-724, available online at http://www.emeraldinsight.com/search.htm?st1=Are+budgets+useful\&ct=all\&ec=1\&bf=1, accessed on 15 May 2013

2. Assenso-Okofo O., Ali M. J., Ahmed K., 2011. The Development of Accounting and Reporting in Ghana, The International Journal of Accounting, Volume 46, Issue 4, December, pp. 459480, http://www.sciencedirect.com

3. Bourmistrov A., Kaarbøe K., 2013. From comfort to stretch zones: A field study of two multinational companies applying "beyond budgeting" ideas, Management Accounting Research, Vol. 24, No. 3, September, pp. 196-211, available online at http://www.sciencedirect.com/science/article/pii/S1044500513000243, accessed on 14 May 2013

4. Boyce G., 2004. Critical accounting education: teaching and learning outside the circle, Critical Perspectives on Accounting, Volume 15, Issues 4-5, May-July, pp. 565-586, http://www.sciencedirect.com

5. Bunce P., Fraser R., Woodcock L., 1995. Advanced budgeting: a journy to advanced management systems, Management Accounting Research, Vol. 6, No. 3, September, pp. 253265, available online at http://www.sciencedirect.com/science/article/pii/S1044500585710177, accessed on 14 May 2013

6. Hansen S. C., Van der Stede W. A., 2004. Multiple facets of budgeting: an exploratory analysis, Management Accounting Research, Vol. 15, No. 4, December, pp. 415-439, available online at http://www.sciencedirect.com/science/article/pii/S1044500504000538, accessed on 30 March 2012

7. Howieson B., 2003. Accounting practice in the new millennium: is accounting education ready to meet the challenge?, The British Accounting Review, Volume 35, Issue 2, June, pp. 69-103, http://www.sciencedirect.com

8. Huang Cheng-Li, Chen Mien-Ling, 2009. Relationships among budgetary leadership behavior, managerial budgeting games, and bugetary attitudes: Evidence from Taiwanese corporations, Journal of International Accounting, Auditing and Taxation, Vol. 18, No. 1, pp. 73-84, available online at http://www.sciencedirect.com/science/article/pii/S1061951808000517, accessed on 01 February 2013

9. Jan van Helden G., Aardema H., ter Bogt H. J., Groot T. L. C. M., 2010. Knowledge creation for practice in public sector management accounting by consultants and academics: 
Preliminary findings and directions for future research, Management Accounting Research, Volume 21, Issue 2, June, pp. 83-94, http://www.sciencedirect.com

10. Joshi P. L., Al-Mudhaki J., Bremser W. G., 2003. Corporate budget planning, control and performance evaluation in Bahrain, Managerial Auditing Journal, Volume 18, Issue 9, pp. 437470, [Online] Available: http://www.emeraldinsight.com/search.htm?stl=Corporate+budget+ planning $\% 2 \mathrm{C}+$ control+and+performance+evaluation+in+Bahrain\&ct=all\&ec $=1 \& \mathrm{bf}=1$

11. King R., Clarkson P. M., Wallace S., 2010. Budgeting practices and performance in small healthcare businesses, Management Accounting Research, Vol. 21, No. 1, pp. 40-55, available online at http://www.sciencedirect.com/science/article/pii/S1044500509000602, accessed on 30 March 2012

12. Kutluk F. A., Donmez A., Utku B. D., Erdogan M., 2012. Expectation of Accounting Professionals From Accounting Education: An Antalya Research, Procedia - Social and Behavioral Sciences, Volume 62, 24 October 2012, pp. 418-423, http://www.sciencedirect.com

13. Libby T., Lindsay R. M., 2010. Beyond budgeting or budgeting reconsidered? A survey of North-American budgeting practice, Management Accounting Research, Vol. 21, No. 1, pp. 5675, available online at http://www.sciencedirect.com/science/article/pii/S1044500509000560, accessed on 30 March 2012

14. Lin Z. J. A., 2008. Factor analysis on knowledge and skill components of accounting education: Chinese case, Advances in Accounting, Volume 24, Issue 1, June, pp. 110-118

15. Neely A., Bourne M., Adams C., 2003. Better budgeting or beyond budgeting?, Measuring Business Excellence, Vol. 7, No. 3, pp. 22-28, available online at http://www.emeraldinsight.Com/search.htm?st1=Better+budgeting+or+beyond+budgeting\&ct= all\&ec $=1 \& b f=1$ accessed on 15 May 2013

16. Reid P., 2002. A critical evaluation of the effect of participation in budget target setting on motivation, Managerial Auditing Journal, Volume 17, Issue 3, pp. 122-129, [Online] Available: http://www.emeraldinsight.com/search.htm?st1=A+critical+evaluation+of+the+effect+of+parti cipation+in+budget+target+setting+on+motivation \&ct=all\&ec $=1 \& b f=1$ 